\title{
O Romance Histórico na Literatura Portuguesa contemporânea
}

\author{
Priscilla de Oliveira Ferreira*
}

\begin{abstract}
Resumo: Este trabalho analisa como os autores contemporâneos revisitam o passado e dialogam com a História portuguesa. Observamos duas tendências do dito romance histórico contemporâneo, enquanto alguns autores seguem o modelo tradicional (reprodução), outros inovam e olham para trás com um novo olhar, são mais críticos e apostam em inovações lingüísticas e estilísticas, incluindo utilização de novas disposições e marcas tipográficas. Fernando Campos, Domingos Freitas do Amaral e Miguel Sousa Tavares representam o primeiro grupo, autores modernos que adotam um estilo tradicional e conservador, tanto na temática quanto na narrativa. Para exemplificar um outro tipo de diálogo com o passado, escolhemos Lobo Antunes, José Saramago e Mário de Carvalho, autores de estilos bem diferentes que, em comum, têm justamente a subversão e o questionamento.
\end{abstract}

Palavras-chave: romance histórico; romance português contemporâneo; historiografia.

\begin{abstract}
This essay analyses how the contemporary authors re-visit the past and talk to the Portuguese History. We observe two tendencies of the historical contemporary novel. While some authors follow the traditional reproduction model, others innovate it and look backwards with a new glance, being more critical and betting on linguistic and stylistic innovations, including the use of new arrangements and typographical marks. Fernando Campos, Domingos Freitas do Amaral and Miguel Sousa Tavares represent the first group of modern authors, who adopt a traditional and conservative style both in theme and in narrative. To exemplify another type of dialog with the past, we chose LoboAntunes, José Saramago and Mário de Carvalho, authors of quite different styles, who have subversion and the questioning character in common.
\end{abstract}

Desde os últimos anos do século passado nota-se um grande incremento na publicação de romances que trazem fatos e personagens históricos para o centro de suas ações. Trata-se de uma tendência mundial, não é um fenômeno exclusivo de alguns países. Neste trabalho, pretendemos analisar como é que os autores portugueses contemporâneos revisitam o passado e dialogam com a História do país.

Podemos observar duas tendências do dito romance histórico contemporâneo, enquanto alguns autores seguem o modelo tradicional (reprodução), outros inovam e olham para trás com um novo olhar, são mais críticos e apostam em inovações linguísticas e estilísticas, incluindo utilização de novas disposições e marcas tipográficas.

Analisaremos Fernando Campos, Domingos Freitas do Amaral e Miguel Sousa Tavares como representantes do primeiro grupo, autores modernos que adotam um estilo

\footnotetext{
* Priscilla Ferreira é jornalista, formada pela PUCRS e também graduada em Letras, pela UFRGS. Mestre em Literatura Brasileira, Portuguesa Luso-africanas pela mesma.
} 
tradicional e conservador, tanto na temática quanto na narrativa. Para exemplificar um outro tipo de diálogo com o passado, escolhemos Lobo Antunes, José Saramago e Mário de Carvalho, autores inovadores e ao mesmo tempo contestadores (Saramago com seu ensaísmo, Lobo Antunes com suas experiências de tempo e narrativa e Mario de Carvalho com o estranhamento).

Para esta análise, selecionamos uma obra significativa de cada escritor. De Fernando Campos, falaremos de Cavaleiro da Águia (2005), de Domingos Freitas do Amaral, Enquanto O Ditador Dormia (2006) e também sobre Equador (2003), de Miguel Sousa Tavares. Já do outro grupo, escolhemos Exortação aos Crocodilos (1999), de Lobo Antunes, O Ano da Morte de Ricardo Reis (1984), de José Saramago e ainda, Era Bom Que Trocássemos umas Idéias Sobre o Assunto (1995), do escritor Mário de Carvalho.

Mas, afinal, o que é um romance histórico? Quais são as características que permitem que o romance seja definido como tal? Esta é uma das questões que este trabalho pretende abordar. A discussão entre História e ficção é tão antiga quanto à teorização da arte ocidental e remonta aos estudos poéticos da Antiguidade. A polêmica ganha destaque novamente no século XIX, nas pesquisas estéticas do Romantismo e o debate se estende ao longo do século XX. Não podemos, então, fugir desta questão, mesmo que este não seja nosso foco principal.

Para falar de características inovadoras no romance histórico contemporâneo, é preciso antes definir o que consideramos como romance histórico clássico. A História sempre foi fonte inesgotável de inspiração para os romancistas, mas o que percebemos nos últimos anos é que, enquanto alguns autores revisitam o passado para questionar, outros voltam para ressaltar e destacar os feitos portugueses. A questão é esta, por que, nos dias de hoje, alguns romancistas optam por estilo tão tradicional de narrativa? Se pensarmos no mundo em que vivemos, de tantas incertezas, de insegurança urbana, de relacionamentos precários, tanto afetivos quanto profissionais, numa sociedade com excesso de informações (definida por Zygmunt Bauman como modernidade líquida), o romance, que é o espelho privilegiado do mundo, como diz Mireille Calle-Gruber, não deveria ser também caótico e retratar este caos? Este trabalho não tem a pretensão de apresentar uma resposta definitiva sobre essas questões, mas apontar alguns caminhos possíveis para entendermos essas tendências do romance histórico em Portugal.

A discussão sobre as fronteiras entre História e Literatura vem de longa data, desde o início da teorização da arte ocidental que o assunto é debatido. Ambas são consideradas como espelhos da humanidade e pretendem representar a realidade. Mas como definir onde termina a representação e começa a criação? Historiadores e teóricos da literatura divergem sobre as 
fronteiras entre as duas áreas. Alguns defendem que os limites são tão tênues que muitas vezes desaparecem.

Ambos pretendem representar a realidade e são construídos por meio da linguagem, estruturando-se em relações temporais e espaciais. Entretanto, se a História parece vir assinalada pela competência em reconstruir fatos e feitos do passado remoto ou recente, buscando apreender significados, essa é uma tarefa da imaginação do presente que, quando se lança à interpretação dos fatos e acontecimentos, se submete ao recurso das fontes documentais. (NIEDERAUER, 2007, p.22)

Não é possível entrar nessa discussão sem falar em Aristóteles. Afinal, os primeiros limites entre História e Literatura já são discutidos na clássica obra do filósofo, onde afirma que a poesia, por falar verdades possíveis ou desejáveis, encerra mais filosofia, elevação e universalidade, já a História retrataria verdades acontecidas, não universais.

[...] é evidente que não compete ao poeta narrar exatamente o que aconteceu; mas sim o que poderia ter acontecido, o possível, segundo a verossimilhança ou a necessidade. $\mathrm{O}$ historiador e o poeta não se distinguem um do outro, pelo fato de o que primeiro escreveu em prosa e o segundo em verso [...]. Diferem entre si, porque um escreveu o que aconteceu e o outro o que poderia ter acontecido. (ARISTÓTELES, 1964, p.278)

De acordo com Aristóteles, o que diferencia a arte do historiador e do poeta é o conceito de imitação; enquanto o primeiro remete-se obrigatoriamente ao que ocorreu, aos poetas cabe falar sobre o que poderia acontecer. Ou seja, o limite aqui é a verossimilhança.

Assim, solidificou-se a separação entre ficção e verdade, base do divórcio entre a arte e a ciência. As noções de história desde o século XIX, que pretenderam a cientificidade da disciplina, ou as manifestações do realismo e do naturalismo na literatura do mesmo período, tiveram como fundamento essa distinção. (MENDONÇA, 2009)

No início do século XIX, quando surge o romance histórico, a maioria dos historiadores acredita e defende a necessidade de comprovação dos fatos, concebe a História como ciência exata e se obriga a provar, através de documentos, que estão narrando um fato ocorrido e não imaginado. O positivismo e seu cientificismo acabam consolidando a teoria de que a Literatura não servia como fonte de conhecimento, já que misturava fatos reais e imaginários. Essas idéias predominam até o início do século $\mathrm{XX}$, quando, com o surgimento da Nova História, essas certezas começam a ser questionadas.

Os questionamentos a respeito do próprio estatuto da História e as tentativas de compreender o papel social do historiador permitiram que o processo de produção do texto histórico também fosse repensado. E aqui, novamente Literatura e História interagem, dessa vez não são os fatos históricos que servem de fonte para as narrativas, mas as teorias literárias que passam a ser usadas como apoio à historiografia. Como diz Georges Duby, a História é um gênero literário, já que só existe através do discurso (cf. Roani, 1998). 
O surgimento da História Nova trouxe consigo a certeza de que a ressurreição integral do passado, pretendida pelos historiadores não pode ser plenamente concretizada, pois existem lacunas, fendas, vazios e silêncios que são irrecuperáveis por mais rigorosa que seja a investigação histórica. Por causa disso, o discurso histórico configura-se como um trabalho organizado com base em fontes selecionadas em detrimento de outras. [...] A corrente da História Nova questiona esses conceitos absolutos, pela consciência de que, em História, tudo é discurso sobre algo que aconteceu ou que acontece com o ser humano. Discurso elaborado através de uma narração que, imaginariamente, no momento presente, lança-se à tentativa de resgatar e recompor o real do tempo passado. (ROANI, 1998, p.31)

No momento em que afirmamos que em História tudo é discurso, reafirmamos elos entre a literatura e a historiografia. Um fato narrado é sempre do ponto de vista do narrador, seja ele historiador, contista, jornalista. Não existe imparcialidade, há sempre uma intencionalidade, seja no texto ficcional ou histórico, não importa. Como afirma a pesquisadora Silvia Niederauer, a História finge ao tentar recuperar o fato histórico na sua totalidade, pois "ao recriarem o passado que a narrativa presentifica, o historiador e o ficcionista apresentam o mundo criado, que se reconfigura através da leitura" (2007, p.30).

A ciência histórica conheceu um avanço prodigioso: renovação, enriquecimento das técnicas e dos métodos, dos horizontes e dos domínios. Mas, mantendo com as sociedades globais relações mais intensas que nunca, a história profissional e científica vive uma crise profunda. $\mathrm{O}$ saber da história é tanto mais confuso quanto mais o seu poder aumenta. (ROANI, 1998, p.31)

\section{Mas o que é um romance histórico?}

O Romance Histórico, na sua definição mais clássica, é aquele em que o enredo se passa entre acontecimentos históricos. Ou seja, o autor situa a ação num tempo passado, procurando reconstituir uma época. A narrativa combina minuciosa reconstituição de ambientes e costumes de épocas passadas com enredo literário, que cria ou amplia tramas para compor suas histórias.

A origem do Romance Histórico estaria nos primeiros anos do século XIX e o gênero ganha espaço e se firma na literatura junto com o romance (que no início também não é levado a sério como arte). Para os românticos, a História era a lente preferida para compreender o mundo, como afirma Maria Lúcia Dias Mendes.

O interesse pela História vinha ao encontro do novo perfil do leitor. Após a Revolução Francesa e a instituição do ensino laico e obrigatório, há um aumento do número de leitores e uma conseqüente mudança de interesse: o público do classicismo, afeito às discussões sobre poéticas, de gosto refinado, conhecedor das novidades na Arte, torna-se um público burguês, sem formação literária, em busca, sobretudo, de uma forma de lazer (WITTMANN, 1987, p. 364).

Os primeiros gêneros a apresentarem a História como pano de fundo para a narrativa foram o romance gótico pré-romântico e o romance de aventuras. Usada como couleur locale, a história proporcionava um tom diferente, reforçando o gosto pelo exótico em enredos que pouco primavam pela originalidade. (MENDES, s.d.) 
O escritor Walter Scott (1771-1832) é quem consolida o estilo, por isso muitos o consideram como criador do clássico romance histórico. Surgiram alguns títulos antes com temática histórica, mas a escolha da época era apenas um detalhe, uma vez que os costumes e a psicologia dos personagens remeteriam mais à própria época do romancista do que a tempos passados. É com Scott que o romance ambiciona recriar épocas e mundos. Ele tenta descrever, através da escrita, fatos e personagens tal qual teriam existido, recurso que chama de “autenticidade da cor local” (MENDES, 2008, p.2). Inspirado na história da Inglaterra para escrever romances de enredo medieval, como o clássico Ivanhoe (1819), Scott foi o primeiro escritor a fazer fortuna com o gênero.

Segundo Lukács (cf. FERNANDES, s.d), que estudou profundamente o assunto, foram precursores do romance histórico as narrativas da história antiga, os mitos da Idade Média e antigos relatos chineses e indianos. Luckács considera informação histórica, cor local, exotismo, valorização do exterior, evocação de civilizações desaparecidas, apresentação do passado como uma realidade acabada, sentimentos coletivos e representação de personagens e tipos, características deste tipo de narrativa ficcional.

Os intelectuais românticos tinham grande interesse pelo passado, principalmente o nacional. É uma fase de formação da identidade nacional, de consolidação da idéia de nação. Os escritores apresentam, nessa época, uma grande preocupação com datas e elementos históricos usados na ficção, preocupação semelhante à dos historiadores que tencionam narrar os fatos como realmente ocorreram e, para isso, baseiam-se em documentos e registros históricos, em busca de uma fidelidade utópica.

Se, por um lado, a História apaixonava os românticos, que recorriam a documentos e registros sobre o passado medieval, por outro, a criação de universos fictícios e referenciais, uma espécie de efabulação com base histórica dominou as produções do período na Europa e também em Portugal (cf. BRAGA, 1984, p.97).

Em Portugal, quem introduziu o romance histórico foi Alexandre Herculano (18101877), que tinha Walter Scott como modelo. O escritor tentava compensar alguns arroubos apaixonados típicos da escola romântica com a serenidade racionalista, e seguia os ditames do Romantismo, ambientando suas narrativas na Idade Média.

A relatividade aposta à veracidade dos textos, está na base, pensamos nós, de toda a construção do romance histórico, mesmo se autores como Herculano pretendem fazer acreditar no papel didático das obras. Num texto intitulado "A Velhice", ele afirma: "Quando o caracter dos indivíduos ou das nações é sufficientemente conhecido, quando os monumentos e as tradições, e as chronicas desenharam esse caracter com pincel firme, o novelleiro póde ser mais verídico do que o historiador; porque está mais habituado a recompor o coração do que é morto pelo coração do que vive, o genio do povo que passou pelo do que passa. Então de um dicto, ou de muitos dictos elle deduz um pensamento ou muitos pensamentos, não reduzidos á lembrança 
positiva, não traduzidos até materialmente; de um facto ou de muitos factos deduz um affecto ou muitos affectos, que não se revelaram. Esta é a história intima dos homens que já não são: esta é a novela do passado. Quem sabe fazer isso chama-se Scott, Hugo, ou De Vigny, e vale mais, e conta mais verdades que boa meia-dúzias de historiadores". (BRAGA, 1984, p.98).

Como podemos confirmar, a relação entre História e Literatura, entre quem diz a verdade e quem mente sobre o passado, vem mesmo de longa data. Tanto o historiador, ao recontar fatos reais, quanto o escritor, ao recorrer a fatos históricos para ilustrar suas narrativas, fazem suas seleções, buscam sugestões, contextos, imagens. Alguns leitores chegam a considerar a literatura como outra leitura da história, acreditando que a inserção desta no texto literário contribui para o seu enriquecimento. Historiador e romancista tentam recuperar e mimetizar o real, de modo "que o fingere encontra-se nos textos de ambos os escritores e se torna elemento dos processos de construção tanto da história quanto da literatura" (NIEDERAUER, 2007, p.30)

A configuração histórica, por conseguinte, vincula-se a uma operação nitidamente literária reveladora, em seus mecanismos, do componente ficcional presente na narrativa histórica. Desse modo, os episódios distanciados no tempo são refamiliarizados, sendo que a narrativa histórica não constitui apenas um modelo de acontecimentos e processos passados. Ela é também um sistema de signos, que aponta para um ícone da estrutura desses acontecimentos na tradição literária vigente, o qual, por sua vez, é a forma essencial de explicação da vida.

Se essa tem na finalidade sua característica, a História também finge ao tentar recuperar o fato histórico em sua totalidade. Não se pode esquecer também que, ao recriarem o passado que a narrativa presentifica, o historiador e o ficcionista apresentam o mundo criado, que se reconfigura através da leitura. O texto final é sempre resultado da leitura da realidade, daí que o leitor do discurso histórico, tal como o leitor do discurso ficcional, integra o texto, atualizando-o e se responsabilizando pela ficcionalização da História e pela historicização da ficção. (idem, ibidem)

No romance histórico, segundo estudos de Lukács, ocorre a representação dos acontecimentos e o desenrolar do processo histórico, com a criação ficcional de um microcosmo que concentra e generaliza, que condensa e expande. Isso significa que o romancista ilumina um momento ou aspecto do passado para mostrar uma realidade social e cultural através do mundo ficcional criado.

Ainda de acordo com os estudos de Lukács, no romance histórico interagem dois tipos de personagens: "protagonistas-tipo", que de modo algum podem agir em desacordo com o tempo em que está inserido nem destoar do espírito vigente na época, e convivendo com estes estão figuras históricas cuja existência é mencionada e comprovada pelos registros históricos.

A ficção pode reconstruir os elementos propriamente ditos históricos, mas, a ficção pode mudar os fatos que conhecemos como verdades históricas? Questiona o crítico Carlos Reis (1992), para quem esta é a questão central entre ficção e História. Para ele, há duas respostas: do ponto de vista ontológico, "ninguém pode impedir um romancista de construir os desfechos que ele julga necessários"; do ponto de vista pragmático, "a ficção não os 
transforma porque eles funcionam como cenários enquadrando as personagens que, de um ponto de vista semântico, são condicionadas por esses mesmos cenários” (p. 142). Esta seria a fronteira entre ficção e realidade. Sobre essa questão, Carlos Reis cita o estudo sobre romance histórico de Isabel Román:

Parece claro que o fracasso do romance histórico está baseado na contradição de que existe entre o desejo de reconstruir uma realidade passada e a impossibilidade real de consegui-lo totalmente. Quando se começou a questionar os romances de Walter Scott, o mestre do gênero, por causa de seus erros históricos, se desencadeou a polêmica sobre o objetivo primordial do romance: verdade ou verossimilhança? A posição e a função do narrador começam a ser discutíveis. Questiona-se sua condição demiúrgica e a objetividade que ele persegue e, ao mesmo tempo, a necessidade romanesca torna-se evidente, como algo que não pode ser evitado. É porque a reconstrução histórica é cada vez menos importante diante da ficção. (RÓMAN, apud REIS, 1992).

Concordamos com Rei: no romance histórico, deve prevalecer a lógica da ficção. Mas existem limites para a integração ficcional dos fatos históricos, um desses limites seriam o do reconhecimento por parte dos leitores, o público precisa ser capaz de identificar certas situações e entidades históricas, pois, "se não são reconhecidas, as entidades históricas perdem inteiramente suas raízes históricas”.

\section{História revisitada na literatura portuguesa contemporânea}

Em Portugal, a literatura produzida pós-25 de Abril destaca-se não só pela temática, mas, sobretudo, quanto à linguagem usada. Nos anos 80 e 90, principalmente, notamos uma originalidade nas criações ficcionais, e novamente a História como inspiração. Mas essa produção não pode ser enquadrada como romance histórico tradicional, pois na maioria dos casos, a História é revisitada pelo texto literário não como uma escrita definitiva, mas sim, com um olhar mais crítico, no sentido de entendê-la com suas limitações e como fruto de uma tentativa de resgate do que foi, considerando o status provisório da escrita.

A presença da História em termos de resgate, representação e problematização do passado português é característica da geração que começou a produzir após a Revolução dos Cravos. Nesta geração, enquadram-se ainda autores que já eram consagrados, mas que, com o fim da ditadura, apostam no experimentalismo e em inovações, dialogando também com a historiografia. São produções marcadas pela vinculação à realidade cultural, social e ideológica portuguesa.

Esse investimento na experimentação escritural, na problematização acerca da representação do acontecimento histórico na malha ficcional de inúmeros romances portugueses deste final de século, condiciona e revela outro traço recorrente na ficção portuguesa atual: a valorização da fabulação narrativa, da metaficcionalidade, da intertextualidade e do diálogo do sistema literário com outras áreas de conhecimento e outras artes. (TUTIKIAN, 2002)

A marca da literatura portuguesa produzida no final do século passado é "esse diálogo 
com a História, esse confronto de duas verdades, a verdade histórica e a verdade da ficção, onde a segunda presentifica e critica a primeira, no resgaste da identidade" (TUTIKIAN, 2002). Na contemporaneidade, a busca da identidade passa, inevitavelmente, pela recuperação de certos valores, seja para resgatar uma tradição ou construir uma nova. Esse diálogo com o passado, tão presente nas narrativas ficcionais do final do século, servem não apenas como resgate, mas como reflexão. “Através, principalmente, do dialogismo, memória, história e ficção se permeiam" (idem, ibidem).

Na contemporaneidade, o que se tem é uma impossibilidade total de comunicação, de uma comunhão, ou mesmo de um elo. Cada sujeito parece uma ilha e mesmo os pontos de vista parecem inconciliáveis. Essa problemática moderna é encarada de forma completamente diferente por cada autor. Lobo Antunes prefere estilhaçar a pretensa unidade narrativa do modelo romanesco. $\mathrm{O}$ autor opta por vários ponto de vista, várias vozes, vários tempos narrativos cruzando-se em uma teia, que mantém sempre uma noção de incerteza.

Lobo Antunes arrebata seus leitores, manipula suas emoções. Para ter uma noção de entendimento exige deles um mergulho caótico, quase sensorial, em um fluxo violento que obedece aos ditames da memória, imprecisa, multifacetada e cambiante quando nos detemos sobre ela. Antunes é um problema para quem tem a mania ou o gosto pela classificação. Como categorizar sua obra e sua persona, ambas tão únicas no cenário artístico contemporâneo? Um problema classificatório que o próprio autor se dá por satisfeito em provocar; o autor já disse em mais de uma entrevista que um artista e um intelectual exercem papéis diferentes, e raros são os que combinam as duas coisas. Ele, assumidamente, diz que não é um desses, que é apenas artista, e por isso não lhe cabe definir ou explicar sua obra, apenas escrevê-la - o que ele faz com paixão e desespero.

No livro Exortação aos Crocodilos (ANTUNES, 2001), são quatro vozes femininas narradas em primeira pessoa, caudalosos fluxos de consciência. O romance é construído através do cruzamento dessas vozes, em tempos e momentos diferentes, vozes que narram o pensamento dessas mulheres. Caminhos que se cruzam, histórias que se intercalam. O todo não existe, o que há são fragmentos.

Neste romance em questão, Lobo Antunes também dialoga com a História, mas de modo completamente diferente do convencional. O contexto aparece tão fragmentado quanto seus personagens. Através dessas mulheres que despejam emoções sobre os leitores é que tomamos conhecimento de quando se passa a história. As quatro personagens pactuam com seus homens, são cúmplices silenciosas das atrocidades que cometem. 
O destino das personagens se cruza pelas relações que estabelecem com antigos policiais da PIDE que torturam comunistas e organizam atentados de direita. Esse grupo saudosista do regime de Salazar acredita que pode pôr fim a Revolução dos Cravos. Conspiração esta, apoiada por militares espanhóis, pelo embaixador americano e por agentes secretos da África do Sul.

Esta conjuração realmente existiu, agrupada em torno do general Spínola, e realmente custou a vida de comunistas, democratas e do primeiro ministro Sá Carneiro. A genialidade de Lobo Antunes é falar dela apenas indiretamente, através do envolvimento mais ou menos definido dessas quatro mulheres. Essa mistura de emoções íntimas, de delírios oníricos, de reflexões irônicas ou desiludidas e de cenas de massacres, de torturas e de atentados, coloca de uma forma inteiramente nova uma das questões mais antigas que a humanidade enfrenta: o mal. Nenhuma resposta é proposta, muito menos uma "compreensão" qualquer. ${ }^{1}$

Esse olhar para o passado é provocativo e faz o leitor pensar sobre o que estava acontecendo naquele período. Longe de ser glorioso, o passado muitas vezes é vergonhoso. E é também um passado não muito glorioso o pano de fundo do romance $O$ Ano da Morte de Ricardo Reis, de José Saramago (2000). O romance se passa no ano de 1936, período em que os regimes totalitários e seus ditadores estão se consolidando na Europa (Hitler na Alemanha, Mussolini na Itália, Franco na Espanha) e Portugal completa dez anos de ditadura.

O resgate histórico de Saramago distancia-se do modelo tradicional dos romances históricos. Concordamos com Roani, quando afirma que o universo ficcional saramaguiano estabelece um discurso que se aproxima e dialoga com o enunciado histórico, "mas que abraça a possibilidade de dizer ou de falar dessa História de uma outra maneira, com uma ampla dose de liberdade e de inventividade" (ROANI, 1998). A História é resgatada e reescrita, o autor mantém uma liberdade discursiva sobre o que foi e o que poderia ter sido.

O dialogismo, marca da produção literária contemporânea, aparece no romance já nas primeiras páginas, aliás, aparece no título da obra, que faz referência ao personagem escolhido, que é duplamente inventado, baseado em outro que já existia na literatura portuguesa. E não por acaso Saramago coloca o mais cético dos heterônimos pessoanos nesse cenário, quando a Europa está em ebulição, "conturbada e agonizante, de valores degradados, onde a liberdade começava a ser um sonho cada vez mais inatingível” (SILVA, 1989).

O mundo representado pela obra deve legitimar a sua cenografia e, para reconstruir o ambiente de Lisboa dos anos 30, Saramago insere no romance textos jornalísticos da época que:

\footnotetext{
${ }^{1}$ Citação retirada do texto Um romance sobre a revolução portuguesa, de autor desconhecido, publicado no Le Monde Diplomatique - Brasil. (www.ala.nletras.com/livros/exortacao_aos_crocodilos.htm)
} 
[...] focalizam a situação histórica portuguesa e européia, nesse ano crucial, em que se consolidam os regimes totalitários de índole fascista. $\mathrm{O}$ aproveitamento desses fragmentos da imprensa portuguesa proporciona uma minuciosa reconstituição das circunstâncias sociais, políticas e históricas de Portugal, criando uma atmosfera cotidiana que bem poderia ser a experimentada por Reis em 1936. (ROANI, 1998, p.9)

Saramago faz uma montagem de discursos heterogêneos, mistura informação objetiva, discursos diretos, discursos irônicos do narrador, discursos emotivos (cf. SILVA, 1989, p.110). A citação de outros textos é implícita neste romance, ou seja, autor e obra não são indicados, aparecem "costurados", absorvidos por outra voz. Essa metalinguagem permite diversas leituras, e a intertextualidade só vai ser percebida se o leitor possuir "repertório ou memória cultural e literária para decodificar os textos superpostos." (SANT'ANNA, 1985)

O narrador assume papel importante na narrativa, conhece o passado, o futuro e o presente. Saramago opta por uma voz narrativa analítica, metódica, que apanha o leitor pela mão deixando pouco espaço para a subjetividade deste e a voz que comenta o narrado e até mesmo discute quais as melhores maneiras de expressar a idéia que pretende comunicar é um lembrete constante ao leitor da natureza artificial da ficção.

Alguns críticos argumentam que a arte pós-moderna não objetiva explorar a dificuldade, mas antes a impossibilidade de se impor um só significado ou uma só interpretação ao texto.

[...] Na metaficção, o artista está presente - não como criador, mas como produtor inscrito de um artefato capaz de promover mudanças sociais através de seus leitores. $\mathrm{O}$ autor manipulador torna-se uma posição a ser preenchida, uma presença a ser inferida pelo leitor. $\mathrm{O}$ mito romântico morre, o autor pensa mais em reescrever do que em criar um texto original. Em virtude disto, a metaficção histórica tornou-se uma das mais populares dentro do gênero. Este tipo de metaficção empenha-se em se situar na história e no discurso, insistindo, ao mesmo tempo, em expressar sua natureza ficcional e lingüística autônoma. (REICHMANN, s/d)

Um narrador manipulador é também o recurso utilizado por Mário de Carvalho no romance Era Bom que Trocássemos umas Ideias sobre o Assunto (2005). A ironia é uma constante na obra, a começar pela advertência inicial: "Este livro contém particularidades irritantes para os mais acostumados. Ainda mais para os menos. Tem caricaturas. Humores. Derivações. E alguns anacolutos”. Pronto, está dado o recado, o leitor já pode se preparar para o que vai encontrar. Ou não.

O romance foge do previsível. Foge também do lugar-comum. Resgata a história recente de Portugal, mas longe de se enquadrar em definições tradicionais de romance histórico. O diálogo com a História do país está lá, sem dúvida. A volta ao passado se dá através do resgate da história dos personagens, e através dos seus caminhos trilhados é que o autor critica o ontem e o hoje. Ao olhar para trás, questiona a Revolução, as mudanças 
ocorridas na sociedade, a burocracia da esquerda (afinal, o que é o socialismo hoje?). A narrativa se passa no presente, mostra uma geração "que envelhece num país muito diferente dos seus antigos (e esquecidos) sonhos"2.

O diálogo proposto entre narrador e leitor é a tônica da narrativa. Ironia, sarcasmo, deboche é o que não falta, afinal, a ficção pós-moderna não aceita mais discursos totalizadores e autoritários.

Dessa forma, a história passa a ser revisitada pelo texto literário, não como uma escrita definitiva, mas sim com um olhar mais crítico, no sentido de entendê-la com suas limitações e como fruto de uma tentativa de resgate do que foi, considerando o status provisório dessa escrita. Sob tal perspectiva, o passado é retomado pelo viés da reavaliação, a partir do momento em que se revela por meio dos signos da escrita, os quais não se isentam da valoração a respeito do fato narrado. Nesse ponto, as paralelas da história e da literatura se cruzam, solidarizando-se, e se mostram aptas ao encaminhamento da discussão sobre suas relações no seio do gênero romanesco. (WHITE, 1992)

O narrador de Mário de Carvalho é intruso e adivinho, antecipa acontecimentos, comenta o narrado e faz questão de avisar o leitor o tempo todo que se trata de uma narrativa ficcional, muito parecido com o que faz Saramago. É o narrador não digno de confiança de Paul Ricouer (1997), que parece jogar o tempo todo com a sagacidade, a paciência e a cumplicidade do leitor. A história começa a desenrolar somente a partir da página 17:

E porque já vamos na página dezesseis, em atraso sobre o momento em que os teóricos da escrita criativa obrigam ao início da acção, vejo-me obrigado a deixar para depois estas desinteressantes e algo eruditas considerações sobre cores e arquiteturas, para passar de chofre ao movimento, ao enredo. Na página três já deveria haver alguém surpreendido, amado, ou morto. Falhei a ocasião de 'fazer progredir' o romance. Daqui por diante, eu mortes não prometo, mas comprometo-me a tentear algumas surpresas. (CARVALHO, 2005, p.17)

O personagem principal é um herói fracassado. Joel Strosse, um homem de 50 anos, burocrata, que vive em descompasso com o seu tempo, tanto que resolve acreditar no comunismo como saída de seus problemas, e decide entrar para o Partido Comunista Português, quando isso não significa mais nada. Através desse herói complexado, o narrador apresenta os demais personagens e as situações econômicas e políticas de Portugal. E revisita o passado, de forma crítica e irônica.

[...] o romance de Mário de Carvalho revela um simulacro, não apenas da narrativa, mas da própria sociedade pós-moderna, que retrata a ruptura dos modelos tradicionais na tentativa de criar novos moldes de possibilidades sociais, amplamente falando. Visto sob esse prisma, o simulacro (simulação), com base no real, o extrapola, pois, partindo dele, não o copia, mas cria uma outra dimensão, desvelando uma outra realidade. A intenção, ao que parece, é tornar perceptível o questionamento acerca da narrativa e, por extensão, da sociedade atual.

\footnotetext{
${ }^{2}$ Trecho retirado da contracapa de CARVALHO, Mario de. Era Bom que Trocássemos umas Ideias sobre o Assunto. São Paulo: Companhia das Letras, 2005.
} 
Desterritorializa, dessa forma, a realidade, deixando-a em suspenso, obrigando-nos a observar, sob outros pontos de vista, o que está encoberto. Os espaços intencionais criados por uma narrativa inquietante (como é o caso dessa), que coloca sobre um de equilibrista nossas certezas acerca dos elementos constitutivos da narrativa tradicional, por exemplo, interrompem o fluxo convencional de estrutura narratológica, instaurando um outro caminho de percepção. (NIEDERAUER, 2008)

Mário de Carvalho desestrutura o modelo convencional de romance. Usa e abusa desse narrador irônico e questionador que vai conduzindo o leitor pelos meandros da história. Assim como Lobo Antunes e Saramago, Mário de Carvalho também desmitifica o passado português, questiona crenças e valores, e propõe a repensagem, tanto do ontem, como do hoje. Literatura como provocação, como reflexão.

\section{$3 \mathrm{O}$ resgate do romance histórico tradicional nos romances portugueses do século XXI}

O romance histórico tradicional nunca chegou a sair de moda. Assim como a História nunca deixou de ser temática favorita de romancistas. Mas enquanto a geração anterior preocupava-se com renovação estética, experimentação, visão crítica, desmistificação, parece que a literatura produzida nos últimos anos tenta resgatar o modelo tradicional de ficção histórica.

Fernando Campos, reconhecido autor de romances históricos, usa e abusa do passado em suas obras. Um dos personagens que decide recontar a história é a figura mítica de Gonçalo Mendes da Maia, conhecido como o Lidador, no livro O Cavaleiro da Águia (2005). A narrativa aproxima-se do modelo tradicional pela temática e linguagem, ao mesmo tempo em que se afasta ao apostar em tempos narrativos diferentes, que se cruzam.

O que impressiona não é tanto a linguagem, mas a temática, essa volta ao passado mítico e glorioso, sem espaço para críticas e questionamentos. Respeita o que teria sido, baseia-se em dados históricos e cria uma história ao redor de uma personagem clássica e conhecida do público leitor. Personagem que já habitou outros narrativas ${ }^{3}$. As figuras históricas são retratadas com heroicamente e carregadas de sentimentos nobres.

Se os propósitos de quem usa a História em textos que não pretendem propriamente fazer estudos científicos e rigorosos, é o de legitimar comportamentos, opções ou, até, códigos nacionais, que necessitam da construção de um passado, verossímil, mas não necessariamente, verdadeiro, então não será de estranhar que apareçam textos, de credibilidade duvidosa, mas, inegavelmente, fundadores de paradigmas essenciais. (MARINHO, 2009)

Fernando Campos, em O Cavaleiro da Águia, intercala duas narrativas. A história do Lidador, que teria sido escrita por cronistas da época, sendo lida pelo Cônego e por Randulfo,

\footnotetext{
${ }^{3}$ Por exemplo, A morte do Lidador, de Alexandre Herculano.
} 
cujo destino vai se cruzar com o do herói histórico. Dividido em capítulos e intermezos, para atrair o leitor moderno, o autor utiliza o recurso do suspense, cria uma trama policial paralela com a história narrada pelos cronistas.

O carácter inacabado da História só pode ter como contraponto o carácter inacabado da Literatura. Por isso se continuam a escrever romances ou contos com personagens do passado, para consolidar o sujeito com a memória, individual e colectiva, para o situar num tempo reversível e utópico. (MARINHO, 2009)

No final do romance, Campos apresenta um "epílogo primeiro", que desvendaria o mistério. Ou não. Já que atrelado ao epílogo traz uma nota de rodapé questionando a veracidade da história narrada, não da que contavam os cronistas, mas a narrada pelo Cônego. Esse diálogo com o leitor é característica da literatura contemporânea, que deixa claro o caráter dúbio do narrador, que não é digno de confiança, principalmente por estar em primeira pessoa.

Nas notas do autor, no final do livro, percebe-se sua preocupação em esclarecer sobre suas fontes e principalmente com o caráter educativo da obra. Pois o romance histórico tinha também essa pretensão: ensinar através da literatura.

Embora a figura central deste livro seja Gonçalo Mendes da Maia, a verdade é que o autor, não esquecendo os graves problemas que hoje se levantam entre o mundo cristão e o mundo árabe, quis dar um sentido universal à sua visão dos dissídios entre os homens. E, na sociedade peninsular dos séculos XI e XII, a par dos horrores da guerra entre Cristãos e Árabes, entre cristãos e cristãos e entre árabes e árabes, há exemplos de compreensão e humildade, de harmonia, alianças, casamentos com geração. (CAMPOS, 2005)

O jornalista Domingos de Freitas do Amaral (2006) opta por retratar um passado mais próximo. Glorioso, glamoroso, mas quase esquecido nos dias de hoje. Retrata no romance Enquanto O Ditador Dormia a Lisboa do início dos anos 40. Em 1941, em plena II Guerra Mundial, a cidade tinha uma posição privilegiada, tudo acontecia enquanto o ditador dormia. Como Salazar habilmente manteve a neutralidade de Portugal, mesmo dividido entre a simpatia ao nazi-fascismo e à histórica aliança com a Inglaterra, a cidade recebia refugiados de toda a Europa, e era o caminho de fuga para a América.

Segundo o autor, os personagens são fictícios, mas suas vivências e descrições são reais. Podemos entender que ele quer dizer que era possível existir naquela Lisboa uma personagem como o espião luso-britânico Jack Gil, já que existiu uma rede de espionagem que tentava desmantelar o grupo de espiões nazistas. A história é narrada em primeira pessoa, são as memórias do ex-espião, 50 anos mais tarde, quando já com 80 anos retorna a Lisboa para o casamento do neto. Ao chegar na cidade, surgem as recordações daquele tempo efervescente, das coisas que aconteciam quando Salazar dormia. 
Novamente nos deparamos com um romance histórico no estilo tradicional, que resgata um momento da história, contextualiza a obra, tenta manter-se fiel ao tempo que escolheu, e, a partir daí, cria sua ficção. Sem pretensões maiores do que contar uma boa história e resgatar uma época quase esquecida, enaltecendo Lisboa e Portugal e mostrando que o país não foi o centro do mundo apenas na época das navegações...

Nada, de repente, existia. A não ser Lisboa, cinquenta anos atrás. A minha Lisboa, onde amei tanto e tantas vezes. A minha Lisboa, das pensões e dos espiões, dos barcos ingleses e dos submarinos alemães; a Lisboa das ligas da Mary em cima de um lençol branco; a Lisboa dos cocktails no Aviz enquanto eu perseguia Alice; a Lisboa do penteado "à refugiada" da minha noiva, a Carminho; a Lisboa dessa menina linda, frágil e alemã, Anika, por quem arrisquei o pescoço; a Lisboa de Michael... (AMARAL, 2006, p.11)

Segundo o autor ${ }^{4}$, o livro é neutro, não critica nem concorda com Salazar. Diz ele que a obra em questão não é política. Pelo que podemos perceber, o escritor e jornalista tenta não se posicionar. Em entrevista a José Eduardo Biscainho, Domingos do Amaral relata que o que motivou-o a escrever o livro foi sua paixão pela II Guerra Mundial:

[...] uma paixão que vem desde a infância, em que lia livros de banda desenhada, histórias ilustradas e via séries televisivas sobre o tema. Ao longo do tempo, o autor leu biografias, romances e livros de História sobre esse tempo, mas era sempre sobre a guerra na Rússia, na Normandia, no Pacífico ou em Itália. Só depois dos seus 30 anos se deu conta que, mais do que se pensa, a Segunda Guerra Mundial foi um fenómeno muito presente na vida dos portugueses. Embora Portugal não tenha participado na Guerra, "a Guerra entrou por Portugal adentro", tal como o mesmo refere na entrevista. À medida que avançava na investigação, o autor ficava cada vez mais fascinado com a riqueza histórica dessa época, e foi então que nasceu a necessidade de escrever uma história sobre alguém que vivera em Lisboa durante os anos da Segunda Guerra Mundial, e assim surgiu o livro Enquanto Salazar dormia. ${ }^{5}$

Já o escritor Miguel Sousa Tavares (2004), também jornalista, escolhe como cenário o conturbado período da decadência da Monarquia em Portugal para retratar no romance Equador. A narrativa do seu livro de estréia se desenrola na colônia de São Tomé e Príncipe e pode ser enquadrada como romance histórico ela mais clássica definição do gênero: cor local, personagens referenciais de primeiro plano, evocação fiel de um tempo.

A História é revisitada para mostrar uma realidade diferente da que ficou registrada nos livros. Aborda a questão da escravidão nas colônias, muito depois da abolição. Foca também os conflitos entre Inglaterra e Portugal sobre a forma como os trabalhadores eram tratados. $\mathrm{O}$ autor demonstra profunda pesquisa para escrever esta obra que mistura fatos históricos e ficcionais.

O bom vivant Luis Bernardo Valença, protagonista do romance, aos 37 anos recebe do

\footnotetext{
${ }^{4}$ Cf. texto publicado em: http://12razoesparavisitaralmodovar.blogspot.com/2009/05/xix-quinzena-culturalprimavera-no.html

${ }^{5}$ Idem, ibidem.
} 
rei o convite para governar São Tomé e Príncipe e resolver a questão dos trabalhadores rurais, que os ingleses acusam de serem tratados como escravos. Acreditando que pode fazer alguma coisa para mudar a realidade local, ele aceita. Deixa a boa vida em Lisboa e vai para o Equador. O choque entre esse governador culto e humanista com a sociedade local é evidente. E suas tentativas de acabar com o trabalho escravo, vãs.

Em entrevista, conta que idéia de escrever o livro surgiu no anos 90, quando recebeu um livro manuscrito sobre as relações de trabalho nas roças em São Tomé e Príncipe, que seria um relatório a ser entregue ao rei Dom Carlos. Tais registros teriam sido feitos no final da monarquia e descreve a posição portuguesa em relação às acusações inglesas. E, tal qual os românticos, Tavares viaja até as ilhas para conhecer de perto o local onde vai desenrolar sua história, baseada nessas anotações. "Foi aí que tropecei neste episódio da história de Portugal que desconhecia: houve um conflito com a Inglaterra a propósito do trabalho escravo na ilha de S. Tomé e Príncipe. Isso inspirou-me a história e a ilha inspirou-me o resto. ${ }^{6}$

O escritor ficou uma semana por lá, anotando e registrando o que podia. Voltou com a idéia do romance pronta. Mas como tinha uma grande preocupação com a História e em ser fiel a ela, na volta contratou uma historiadora para ajudá-lo:

Enquanto escrevia, contratei uma licenciada em História, Ana Xavier Cifuentes, para verificar uma série de dados. Ela voltou a São Tomé, já em plena escrita do romance, para verificar qual era o nome antigo das ruas, para consultar o Arquivo Histórico de S. Tomé e Príncipe, etc. ${ }^{7}$

Sobre os erros históricos apontados na obra, fez algumas correções, mas depois, tratou de responder que não era historiador, mas romancista. A sua obra é descritiva, os ambientes são detalhados, há uma preocupação com o visual, com o imagético. Diferente de autores como Lobo Antunes e Saramago, por exemplo, se atém a pormenores, como descrição completa do cardápio, que, segundo ele, foi copiada à risca de um menu da época.

Apesar da história se passar na colônia, o ponto de vista continua sendo o do colonizador. $\mathrm{O}$ autor critica a sociedade lisboeta, tão vazia e despreocupada com a realidade das colônias ultramarinas. Ao mesmo tempo, mostra como teoria e prática se distanciam, pois o protagonista adotava um discurso antes de embarcar para o Equador e, apesar de ter tentado permanecer fiel a ele, descobriu que a realidade era muito mais complexa do que imaginava.

Para quem pretende ser tão realista e fiel aos fatos históricos, impressiona que utilize algumas descrições tão inverossímeis. Suas personagens femininas são lindas, sensuais,

\footnotetext{
${ }^{6}$ Trecho de entrevista de Miguel Tavares ao jornal Público, publicada em 13 de dezembro de 2003. Disponível em: http://historiaeciencia.weblog.com.pt/arquivo/045286.html

7 Idem, ibidem.
} 
exuberantes, tanto a escrava que cuida do governador como a emblemática Ann, como podemos observar no trecho a seguir:

E, de repente, a simples visão de Ann, no seu vestido de alças de seda branca, as costas, os ombros e o vale entre o peito altivo descobertos, e uma safira azul pendente num decote que era todo um mundo de promessas, fora suficiente para arrasar e deitar por terra todos os seus enganos. Por que não há engano que resista à evidência de uns ombros direitos, a umas costas expostas e macias até à vista e a um peito exuberante, subido, como montanhas desafiando um conquistador. Ann arrasava tudo à volta, sorrindo recatada, quase pedindo desculpas públicas por ser tão bonita e tão devastadoramente desejável. (TAVARES, 2004, p.443)

Apesar de algumas descrições em dissonância com a obra, o autor tenta mostrar uma realidade outra, é ficção, não existiu um Luis Bernardo, mas como as anotações que chegaram até o escritor comprovam, poderia ter existido. Afinal, nem todos eram coniventes com as condições locais, o difícil era se rebelar, como bem mostra Tavares.

\section{Observações finais:}

Enquanto a geração que surgiu pós-74 se voltava para o passado com o intuito de desmitificá-lo, hoje parece que se consolida uma geração com objetivo oposto, que olha para trás a fim de encontrar um passado glorioso do qual possa se orgulhar.

Podemos confirmar isso em várias obras, seja através do resgate de célebre personagem histórico, como fez Fernando Campos em $O$ Cavaleiro da Águia, em que narra a vida de D. Gonçalo Mendes da Maia; seja através das memórias de um ex-espião sobre um período em que Lisboa foi o centro da Europa e teve papel importante na história, como nos primeiros anos da II Guerra Mundial, na obra de Domingos Freitas do Amaral; ou mesmo um mea-culpa sobre a manutenção da escravatura nas colônias mesmo após abolição, como fez Miguel Souza Tavares.

Parece que a história literária é mesmo cíclica, após uma fase de experimentalismos, surge outra de resgate às tradições, muito mais clássica e conservadora, inovando justamente ao fugir dos modelos inovadores e apostar no velho com nova roupagem. Como diz Agustina Bessa-Luís "inventar é o melhor espelho, e o resto não interessa nada".(apud MARINHO, 2009, p.138)

Para representar o caos da sociedade moderna existe de tudo, autores que apostam em fórmulas tradicionais, outros que inovam, uns que fragmentam e estilhaçalham suas narrativas, outros que ironizam e debocham da própria História. Todas as fórmulas são válidas. $\mathrm{O}$ romance, este espelho do mundo, tem muitas faces. 


\section{Referências}

AMARAL, Domingos Freitas do. Enquanto o Ditador Dormia. Rio de Janeiro, Nova Fronteira, 2006.

ANTUNES, António Lobo. Exortação aos Crocodilos. Rio de Janeiro: Rocco, 2001.

ARISTÓTELES. Arte Retórica e Arte Poética. São Paulo: Difusão Européia do Livro, 1964.

BAUMAN, Zygmunt. Modernidade e ambivalência. RJ: Zahar, 1999

BRAGA, Teófilo. O Romance Histórico de Alexandre Herculano. Col, Ulmeiro/Universidade, nº, Lisboa, 1984. Disponível em: http://ler.letras.up.pt/uploads/ficheiros/2643.pdf. Último acesso em:16 ago. 2009

CALLE-GRUBER, Mireille.L'effet-fiction. Paris :A.-G. Nizet,1989

CAMPOS, Fernando. O Cavaleiro da Águia. Lisboa: DIEFEL, 2005.

CARVALHO, Mario de. Era Bom que Trocássemos umas Ideias sobre o Assunto. São Paulo: Companhia das Letras, 2005.

FERNADES, Rinaldo. O herói do meio: uma abordagem da teoria do romance histórico de Georg Lukács. Disponível em: http://www.adufpb.org.br/publica/conceitos/09/art_13.pdf.

HUTCHEON, Linda. Poética do pós-modernismo: teoria, história, ficção. Rio de Janeiro: Imago, 1991.

MARINHO, Maria de Fátima. A Construção da Memória. Disponível em: http://www.lusitanistasail.net/revista/docs/veredas_separata_07.pdf.

MENDES, Maria Lúcia Dias. A presença de Walter Scott e Jules Michelet no romance histórico de Alexandre Dumas. Texto apresentado no XI Congresso Internacional da ABRALIC. Disponível em:

http://www.caminhosdoromance.iel.unicamp.br/estudos/ensaios/Abralic2008/MARIA_M ENDES.pdf_

MENDONÇA, Carlos Vinícius Costa e ALVES, Gabriela Santos. Os desafios Teóricos da História e da Literatura. Disponível em: http://www.anpuh.uepg.br/historiahoje/vol1n2/historialiterat.htm\#_edn6. Último acesso em: 16 ago. 2009

NIEDERAUER, Silvia Helena Pinto. Ao viés da História: Política e Alegoria no Romance de Erico Veríssimo e Moacyr Scliar. 2007, (Tese de Doutorado em Letras - Teoria da Literatura), Faculdade de Letras da PUCRS, Porto Alegre.

. Era bom que trocássemos umas ideias sobre o assunto ou $O$ simulacro da narrativa na pós-modernidade. Letras de Hoje, Porto Alegre, v. 43, n. 4, p. 83-88, out./dez. 2008

REICHMANN, Brunilda T. Reichmann. Que é metaficção? Narrativa narcisista: o paradoxo metaficcional, de Linda Hutcheon. Disponível em: 
http://mestrado.uniandrade.edu.br/links/menu2/publicacoes/metaficcao.pdf .

REIS, Carlos. A ficção portuguesa entre a Revolução e o fim do século. In: Scripta: Revista do Programa de Pós-graduação em Letras e do Cespuc, Belo Horizonte: PUC Minas, 2004

. Fait Historique Et Référence Fictionnelle: Le Roman Historique. Dedalus: Revista Portuguesa de Literatura Comparada. No 2, Lisboa, Cosmos, dez. 1992, p. 141-147. trad: Jane Tutikian.

RICOEUR, Paul. Mundo do texto e mundo do leitor. In: Tempo e Narrativa. Campinas: Papirus, 1997. Volume III.

ROANI, Gerson Luiz: O que está envolvido nesse cerco de Lisboa? (Dissertação de Mestrado - Letras) Universidade Federal do Rio Grande do Sul, Porto Alegre, 1998.

SANT’ANNA. Affonso Romano. Paródia, Paráfrase \& Cia. São Paulo: Ática, 1985.

SARAMAGO, José. O Ano da Morte de Ricardo Reis. São Paulo: Companhia das Letras, 2000.

SILVA, Teresa Cristina Cerdeira. José Saramago: entre a história e a ficção. Lisboa: Publicações Dom Quixote, 1989.

TAVARES, Miguel de Sousa. Equador. Rio de Janeiro: Nova Fronteira, 2004.

TUTIKIAN, Jane. "Entre o nevoeiro, a imobilidade e o sonho: a reconstrução da identidade." In: II Seminário Internacional em Letras; Memória e escrita, 2002, Santa Maria.

WHITE, Hayden. Meta-história: imaginação histórica do século XIX. São Paulo: EDUSP, 1992. 